\title{
TREATMENT OF FLUORIDE BEARING CONTAMINATED WATER USING SIMULTANEOUS ADSORPTION AND BIODEGRADATION IN A LABORATORY SCALE UP: FLOW BIO-COLUMN REACTOR BY JAVA PLUM SEED
}

\author{
TEJ PRATAP SINGH ${ }^{1}$, SANJOY GHOSH ${ }^{2}$, MAJUMDER CB ${ }^{1 *}$
}

${ }^{1}$ Department of Chemical Engineering, Indian Institute of Technology Roorkee, Uttarakhand, India. ${ }^{2}$ Department of Biotechnology, Indian Institute of Technology Roorkee, Roorkee, Uttarakhand, India. Email: cbmajumder@gmail.com

Received: 16 July 2016, Revised and Accepted: 17 September 2016

\section{ABSTRACT}

Objective: Here, we aimed for the treatment of fluoride bearing contaminated water using simultaneous adsorption and biodegradation in a biocolumn reactor by using java plum seed.

Methods: We immobilized Acinetobacter baumannii bacteria on the java plum seed in the bio-column reactor. The water used contained a sample of fluoride with concentration of $20 \mathrm{mg} / \mathrm{L}$. The bed depth service time design model and empty bed residence time were used to analyze the performance the bio-column. We examined and observed closely the effect of different operating parameters such as flow rate of bed depth and initial concentration on this simplified bio-column reactor design model. Desorption experiment was conducted to evaluate the possibilities of regeneration and to reutilize of media.

Results: We observed that the bio-column reactor is capable to reduce the concentration of the pollutants in the effluent water below their permissible limit. Reduction in DO along the bed height of the reactor was also observed, which supports the aerobic nature of the bacteria.

Conclusion: The experimental results were encouraging and indicate that java plum (Syzygium cumini) seed is a feasible option to use as a biosorbent to remove fluoride in the bio-column reactor.

Keywords: Bio-reactor, Simultaneous adsorption and biodegradation, Flow rate, Acinetobacter baumannii MTCC 11451, Physicochemical adsorption, Bed depth service time, Empty bed residence time.

(C) 2016 The Authors. Published by Innovare Academic Sciences Pvt Ltd. This is an open access article under the CC BY license (http://creativecommons. org/licenses/by/4. 0/) DOI: http://dx.doi.org/10.22159/ajpcr.2016.v9s3.14136

\section{INTRODUCTION}

Fluorine with atomic number 9 is the $13^{\text {th }}$ most abundant element of the earth's crust. It constitutes about $0.03 \%$ of earth's crust mass. It occurs mainly in the form of chemical compounds such as sodium fluoride or hydrogen fluoride, which are present in minerals fluorspar, fluorapatite, topaz, and cryolite. Fluoride is frequently encountered in minerals and in geochemical deposits and is generally released into subsoil water sources by slow natural degradation of fluorine contained in rocks. Fluoride is beneficial to health if the concentration (CF) of the fluoride ion (F-) in drinking water is $<1.5 \mathrm{mg} / \mathrm{L}$ (WHO 1994). A higher concentration causes serious health hazards. Even though extensive studies have been conducted, there seems to be no effective cure for diseases caused by fluoride. Therefore, it is advised to drink water having a fluoride concentration less than certain value. Hence, drinking water with $\mathrm{C}_{\mathrm{F}}>1.5 \mathrm{mg} / \mathrm{L}$ (1 mg/L in India) needs treatment (WHO 1994). The concentration of fluoride in industrial wastewater varies from $15 \mathrm{mg} / \mathrm{l}$ to $20 \mathrm{mg} / \mathrm{l}$ after coagulation process. Fluoride waste water industries are glass, electroplating, aluminum, steel, chemical industries, and oil refinery. The ever increasing demand for water has caused considerable attention to be focused toward recovery and reuse of industrial wastewater [2]. In the treated water, amount of element (Fluoride) minimized to come within permissible limits by BSI as shown in Table 1 [1].

Biological and adsorption processes are a common phenomenon in our natural ecosystem. In the environment, organic pollutants are generally degraded by simultaneous adsorption and biodegradation/bioaccumulation (SAB). Purification of waste water is based on $\mathrm{SAB} /$ bioaccumulation involved basically two types of mechanism. The first one common effect of microbial cell and adsorbent [3]. The availability of adsorbents increased the surfaces of liquid-solid phase. Microbial cells, pollutants, enzymes, and oxygen are adsorbed. The physicochemical reaction is also possible due to surface catalysis on the surface of adsorbent [4]. Microbial enzymes Acinetobacter baumannii immobilized to surface of adsorbent bring extracellular biodegradation/bioaccumulation on adsorbed pollutants (Fluoride). Bio-regeneration depends on adsorbent adsorption capacity. It is highly increased and the adsorbent adsorption system is continuing for a long time compared to simple adsorption process. As a result, when simultaneous adsorption and bioaccumulation/ biodegradation occur, the removal efficiency of fluoride and waste water quality is considerably better [5]. The second mechanism is mentioned by many authors [6-8]; they reported opposite results as earlier was described, which explained that the steady decreased in the elimination of pollutants, after several adsorption cycles.

\section{METHODS}

Chemicals

All the chemicals used in this study were of analytical reagent grade and obtained from Himedia Laboratories Pvt. Ltd., Mumbai, India. All the solutions were prepared in milli-Q water $\left(\mathrm{Q}-\mathrm{H}_{2} \mathrm{O}\right.$, Millipore corp. with resistivity of $18.2 \mathrm{M}^{\prime} \Omega$ - $\mathrm{cm}$ ). Fluoride solution of $2000 \mathrm{mg} / \mathrm{L}$ was prepared by dissolving $4.42 \mathrm{~g}$ of sodium fluoride $(\mathrm{NaF})$ in $1 \mathrm{l}$ of millipore water.

\section{Strains and medium}

A. baumannii MTCC 11451is used to complete this study. This bacterium was supplied by Microbial type culture collection, Chandigarh, India. The strains were revived according to the instructions given by MTCC (MTCC guidelines). Cultures were stored on agar plates till further use and were subcultured after every 15-30 days. All inoculations were performed in aseptic conditions in laminar air flow unit (Rescholar Equipment, India). The composition of growth media specific to abovementioned strains in given strains is given in Table 3. 
Table 1: Permissible Limit of various elements in drinking water by BSI

\begin{tabular}{ll}
\hline Parameter & Requirement desireable limit \\
\hline Colour & 5 \\
Turbudity & 10 \\
pH & $6.5-8.5$ \\
Total hardness & 300 \\
Calcium as Ca & 75 \\
Magnesium as Mg & 30 \\
Copper as Cu & 0.05 \\
Iron & 0.3 \\
Manganese & 0.1 \\
Chlorides & 250 \\
Sulphates & 150 \\
Nitrates & 45 \\
Flouride & $0.6-1.2$ \\
Phenols & 0.001 \\
Mercury & 0.001 \\
Cadmium & 0.01 \\
Selenium & 0.01 \\
Arsenic & 0.05 \\
Cyanide & 0.05 \\
Lead & 0.1 \\
Zinc & 5.0 \\
Anionic detergents & 0.2 \\
Chromium as Cr & 0.05 \\
Poly nuclear aromatic & - \\
hydrocarbons & \\
Mineral oil & 0.01 \\
Residual free chlorine & 0.2 \\
Pesticides & - \\
Radio active & \\
\hline & \\
&
\end{tabular}

Table 2: Salient feature of bio-column reactor

\begin{tabular}{ll}
\hline Description & Value \\
\hline Diameter of reactor $(\mathrm{cm})$ & 8.0 \\
Total height of reactor $(\mathrm{cm})$ & 100 \\
Volume of reactor (liters) & 5.03 \\
Number of sampling point $(\mathrm{cm})$ & 5.0 \\
Height of sampling point $(\mathrm{cm})$ & 100 \\
Diameter of sampling point $(\mathrm{cm})$ & 1.25 \\
Total weight of absorbent $(\mathrm{g})$ & 2420 \\
Density of bed $(\mathrm{g} / \mathrm{mL})$ & 0.7166 \\
Actual volume of reactor $(\mathrm{L})$ & 1.623 \\
\hline
\end{tabular}

Table 3: Composition of media for microorganisms

\begin{tabular}{ll}
\hline Micro-organisms & Media compositions (g/l) \\
\hline A. baumannii (MTCC 11451) & Sodium chloride, NaCl (10) \\
& Tryptone (10) \\
& Yeast extract (5) \\
\hline
\end{tabular}

A. baumannii: Acinetobacter baumannii

\section{Acclimatization}

The acclimatization of all four strains in fluoride environment was performed as follows:

The culture was subcultured from agar plate in $100 \mathrm{ml}$ of steam sterilized prescribed media (Table 3) in $250 \mathrm{ml}$ round bottom flask. The media was supplemented with $20 \mathrm{mg} / \mathrm{l}$ of fluoride. The conical flask was agitated/incubated in an incubator shaker (Metrex MO250 , India) at room temperature $\left(30^{\circ} \mathrm{C}\right)$ with an agitation speed of $120 \mathrm{rpm}$ for $24 \mathrm{hrs}$. After $24 \mathrm{hrs}$, the synthetic medium in flask turned turbid indicating significant bacterial growth in the flasks.

\section{Batch biodegradation experiments}

Batch experiments were carried out in $250 \mathrm{ml}$ round bottom flask with working volume of sample $100 \mathrm{ml}$ at $30^{\circ} \mathrm{C}$ and $120 \mathrm{rpm}$ in an incubator cum-orbital shaker (Metrex, M0-250, India). The flask was covered with both cotton plug and aluminum crimp cap. All the flasks containing growth medium were steam sterilized in autoclave at $121 \pm 1^{\circ} \mathrm{C}$ for 45 minutes at 15 psi pressure. All the batch experiments were conducted for the optimization of parameters such as contact time, initial concentration, $\mathrm{pH}$, and dose of adsorbents. Microbial culture grows in $21 \mathrm{hrs}$ and dead phase started after $71 \mathrm{hrs}$ from the study of growth curve of microbial culture. A preliminary test showed that the equilibrium adsorption and biodegradation contact time was obtained after $86 \mathrm{hrs}$. At the end of this period, the solutions were centrifuged, and residual concentrations of fluoride at the equilibrium were determined.

\section{Analytical method}

For biodegradation studies, appropriate volumes of samples were withdrawn and centrifuged using Remi Lab centrifuge at $9000 \mathrm{rpm}$ for 10 minutes. The supernatant was analyzed for fluoride by SPANDS method at $570 \mathrm{~nm}$. The SPADNS (trisodium 2-parasulfophenylazo- 1,8-dihydroxy -3,6-napthalene disulfonate or 4,5 -dihydroxy-3- paraphenylazo-2,7 -naphthalenedisulfonic acid trisodium salt) method of determination of fluoride in drinking water is a simple and a rapid technique with high accuracy. It can be applied directly to most water samples without prior pre-treatment and is not very sensitive to the other ions which are usually found in potable water (Jacobson and Weinstein 1977). The reagent used in this method, i.e., SPADNS - Z ZrOCl2 is a red colored complex, which changes color when it reacts with fluoride. The change in concentration of SPADNS - $\mathrm{ZrOCl} 2$ causes a change in the transmitted light, which is detected by the colorimeter. The reaction between fluoride and SPADNS reagent is rapid, and hence, the samples can be tested within 10 minutes after adding them to the reagent. SPADNS reacts with zirconyl chloride to give a wine - red colored complex which further reacts with fluoride to give a new complex (Fig. 4.1). The bacterial growth was measured as optical density (absorbance) by UV-Vis spectrophotometer (HACH DR. 5000) at $600 \mathrm{~nm}$ after $86 \mathrm{hrs}$ and was expressed in terms of biomass concentration.(mg dry weight/L). [9] Fig. 1 shows various reactions involved in the SPANDS method for estimation of fluoride.

\section{Experimental setup}

This experiment is carried in a bioreactor column of SS pipe with an objective to remove fluoride from industrial wastewater. The schematics diagram of the experimental setup is shown in Fig. 2. SS pipe column of various length $\left(Z_{1}=20, Z_{2}=40, Z_{3}=60, Z_{4}=80\right.$ and $\left.Z_{5}=100 \mathrm{~cm}\right)$ and $8 \mathrm{~cm}$ internal diameter were used while the height of reactor is $100 \mathrm{~cm}$ and net volume 5.03 lit. It was equipped with a total of four equidistant ports (excluding inlet and outlet) of $1.25 \mathrm{~cm}$ diameter for collecting liquid sample along the height of reactor. The top and bottom portion were connected with the main column by two flange joints, supported on SS screen (mesh no: $16 \mathrm{BSS}$, width aperture: $1.00 \mathrm{~mm}$ ). The reactor is filled with weighted amount of Java plum seeds (Bio adsorbent) having a particle size of 2-4 mm as a fixed-bed absorber. The bed was supported and closed by cotton pad and rubber, respectively, to prevent the flow of adsorbent together with the effluent. Then, the bed was rinsed with distilled water and left overnight to ensure a closely packed arrangement of particle without voids, channels, or cracks. Synthetic fluoride solution of known concentration ( $20 \mathrm{mg} / \mathrm{l})$ was fed through a bed of Java plum seeds in up-flow mode to avoid channeling due to gravity and to ensure a uniform distribution of the effluent thought out the column. The experiments were carried out at room temperature. A peristaltic pump was used to control the flow rates $(12,23$ and $40 \mathrm{ml} /$ minutes $)$ and maintained constant during each experiment. Periodic flow rate check carried out by collecting sample at the effluent for a given time and measured using measuring cylinder. A sample of effluent was collected at $1 \mathrm{~h}$ interval and analyzed by spectrophotometric (SPADNS) method for fluoride ion concentration using UV spectrophotometer (Hach, DR 5000). The volume of treated water was measured at $1 \mathrm{~h}$ interval, and the average flow rate was calculated based on these values because the flow rate becomes unstable as the bed depth is high due to a higher flow resistance. The desired breakthrough concentration $\left(\mathrm{C}_{\mathrm{b}}\right)$ was determined at $7.5 \%$ of the initial concentrations $(20 \mathrm{mg} / \mathrm{l})$. 
The empty bed residence time model (EBRT)

The EBRT is a design producer for the design of an absorber. Major design parameters are:

1. EBRT or empty bed contact time (EBCT)

2. Adsorbent exhaustion rate

These parameters can be correlated for a fixed bed column to determine the operating and capital costs of adsorption system [10,11]. Negrea et al. [12] and Guo et al. [13] have been reported that EBCT is a critical parameter in the adsorption processes specially if the adsorption mainly depends on the contact time between the adsorbent and adsorbate.

The EBRT is defined as the time required for the liquid to fill the empty column and it determines the residence time during which the solution treated is become constant with the adsorbent:

$$
\operatorname{EBRT}(\text { minute })=\frac{\text { Bed volume }}{\text { Volumetric flow rate of the liquid }}
$$

The adsorbent exhaustion rate is the mass of the adsorbent used per volume of liquid treated at the breakthrough:

Adsorbent exhaustion rate $(\mathrm{g} / \mathrm{L})=\frac{\text { Mass of adosrbent used }}{\text { Volume of liquid treated at breakthrough }}$

The adsorbent exhaustion rates are plotted against the EBRT values, and a single operating line can be constructed to correlate these two variables. Thus, to select the optimum combination of adsorbent exhaustion rate and the liquid retention time, the operating line should first be established.

The equations 1 and 2 reveal that with the lower adsorbent exhaustion rate, volume treated at the breakthrough point become larger and hence longer EBRT and smaller amount of adsorbent are needed per unit volume of feed treated which implies a lower operating cost; however, larger column will have to used. On the other hand, the higher the adsorbent exhaustion rate, the smaller the EBRT, the higher the operating cost and smaller column are needed which will reduce the construction cost.

\section{RESULTS AND DISCUSSION}

\section{Fixed-bed design models}

The bed depth service time model (BDST), the model (EBRT) and the Thomas model are selected for this study which is used to predict, optimize, and describe the fixed-bed column operation, respectively.

\section{BDST model}

Fig. 3 shows the BDST plots ( $T_{b}$ versus $D$ ), which is constructed from the Table 4 for the influent fluoride concentration of $20 \mathrm{mg} / \mathrm{l}$ and flow rates of 12,23 and $40 \mathrm{ml} /$ minutes at $7.5 \%$ breakthrough time for 20,40 , 60 and $100 \mathrm{~cm}$ bed heights. The coefficients $\mathrm{N}_{\mathrm{o}}$ and $\mathrm{K}$ for the three flow rates are calculated based of equation.

$$
\mathrm{T}_{\mathrm{b}}=\frac{\mathrm{N}_{0} \mathrm{D}}{\mathrm{C}_{0} \mathrm{~V}}-\frac{1}{\mathrm{KC}_{0} \ln \left(\frac{\mathrm{C}_{0}}{\mathrm{C}_{\mathrm{b}}}-1\right)}
$$

Where,

$\mathrm{T}_{\mathrm{b}}$ : Service at breakthrough point $(\mathrm{h})$

No: Bed capacity $\left(\mathrm{mg} \mathrm{cm}^{3}\right)$

D: Packed-bed column depth $(\mathrm{cm})$

v: Linear flow rate through the bed $\left(\mathrm{cm} \mathrm{h}^{-1}\right)$

$\mathrm{C}_{0}$ : Influent fluoride concentration $(\mathrm{mg} / \mathrm{L})$

$\mathrm{C}_{\mathrm{b}}$ : Breakthrough fluoride concentration $(\mathrm{mg} / \mathrm{L})$

$\mathrm{K}$ : Adsorption rate constant $\left(\mathrm{L} \mathrm{mg}^{-1} \mathrm{~h}^{-1}\right)$.

The equation of a straight line on BDST curve can be expressed as $\mathrm{y}=\mathrm{ax}+\mathrm{b}$;

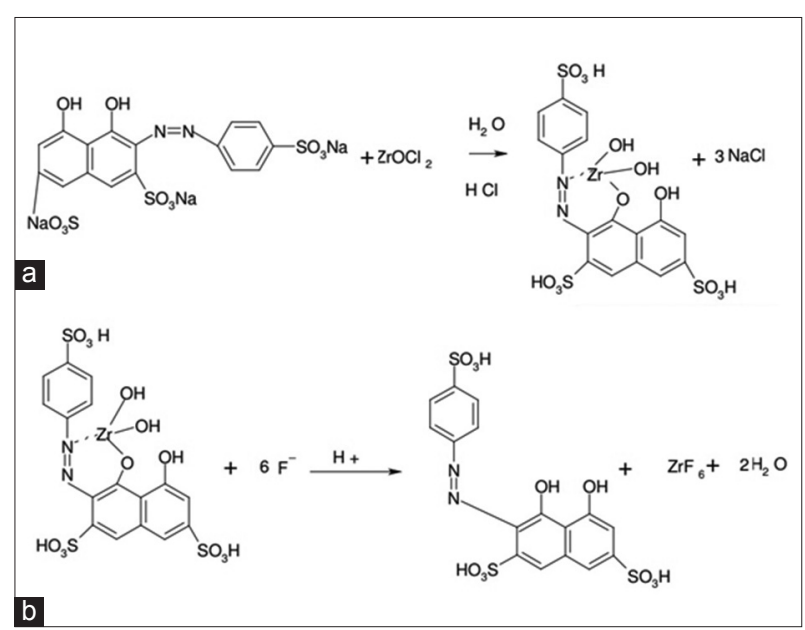

Fig. 1: (a) Formation of the SPADNS - ZrOCl2 complex. (b) Reaction of the complex with fluoride ions

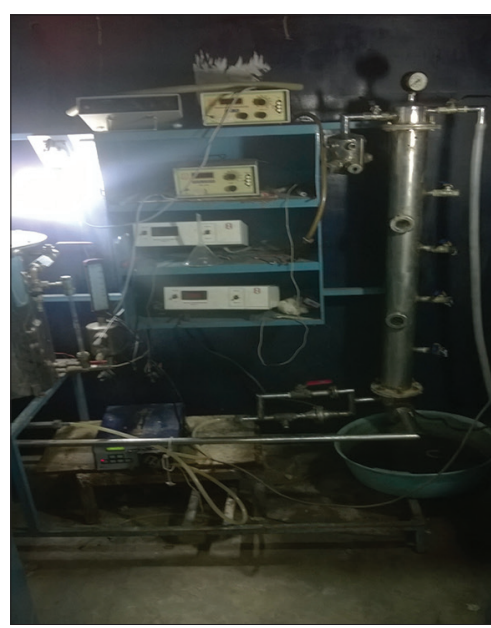

Fig. 2: Experimental setup with biocolumn reactor

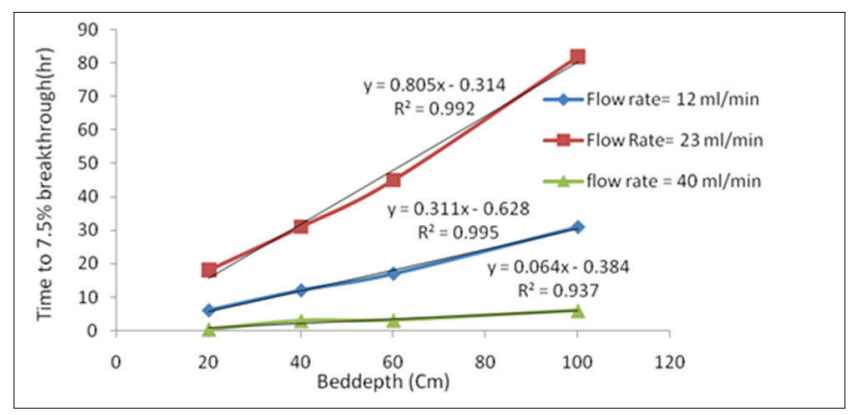

Fig. 3: Bed depth service time model plot at $7.5 \%$ breakthrough in a fixed-bed column at different flow rates

Where,

$\mathrm{y}$ : Service time

$\mathrm{x}$ : Bed depth

a: Slope

b: Ordinate intercept.

The numerical value of the slope $(\mathrm{a})=\mathrm{N}_{0} / \mathrm{C}_{0} \mathrm{~V}$ and the intercept (b) $=\frac{1}{\mathrm{KC}_{0} \ln \left(\frac{\mathrm{C}_{0}}{\mathrm{C}_{\mathrm{b}}}-1\right)}$, the adsorptive capacity of the system, $\mathrm{N}_{0}$ and the rate constant, $\mathrm{K}$, can be evaluated from the slope and intercept of a straight line plotted as the service time against the bed depth from experimental data, respectively. The minimum bed depth $\left(D_{\min }\right)$, which 
represents the theoretical depth of adsorbent able to prevent the adsorbent concentration from exceeding $\mathrm{C}_{\mathrm{b}^{\prime}}$ is obtained when $\mathrm{T}_{\mathrm{b}}=0$, according to the following equation:

$\mathrm{D}_{\text {min }}=\frac{\mathrm{v} \ln \left(\frac{\mathrm{C}_{0}}{\mathrm{C}_{\mathrm{b}}}-1\right)}{\mathrm{KN}_{0}}$

The slope of the line presented by $\mathrm{y}=\mathrm{ax}+\mathrm{b}$ can be used to predict the performance of the bed if there is change in the initial solute concentration $\mathrm{C}_{01}$ to a new $\mathrm{C}_{02}$. Hutchins [14] proposed that the new slope $\mathrm{a}_{2}$ and new intercept $\mathrm{b}_{2}$ can be estimated by equation.

$\mathrm{a}_{2}=\frac{\mathrm{a}_{1} \mathrm{C}_{01}}{\mathrm{C}_{02}}$

$\mathrm{b}_{2}=\frac{\mathrm{b}_{1} \mathrm{C}_{01}}{\mathrm{C}_{02}} \frac{\ln \left(\frac{\mathrm{C}_{02}}{\mathrm{C}_{\mathrm{b}}}-1\right)}{\ln \left(\frac{\mathrm{C}_{01}}{\mathrm{C}_{\mathrm{b}}}-1\right)}$

McKay et al. [15] stated that if design data are required for a change in volumetric flow rate of solute to the some adsorption system, the new slope with the intercept remaining unchanged can be written as:

$\mathrm{a}_{2}=\frac{\mathrm{a}_{1} \mathrm{Q}_{1}}{\mathrm{Q}_{2}}=\frac{\mathrm{a}_{1} \mathrm{v}_{1}}{\mathrm{v}_{2}}$

\section{Effect of flow rate}

The performance of a bio-column reactor is highly determined by its flow rate. Contact time is directly proportional to flow rate thus increasing in flow rate will increase in contact time which will eventually result in less concentration of pollutants in the output. However, we must consider the fact with increase in flow rate treatment capacity of the reactor decreases. In literature, a wide range of flow rate values has been used In general, for laboratory purposes flow rate with a low value is used to treat industrial water by indigenous bacteria. In the said process, tap water (without inoculated media) is passed for 2-3 days to get a biolayer of bacteria. However, the longer flow rate is normally used for the treatment of industrial effluents, where bacteria inoculated media is used to develop the bio-layer on the adsorbent bed. In this study, we choose three flow rate $(12,23$ and $40 \mathrm{ml} /$ minutes) and study the effect of flow rate on the fluoride concentration in the treated water. Fig. 4 depicts data collected from the top of the reactor. This follows the trend observed [16]. From Fig. 4, it is evident that for all the flow rate values the fluoride concentration in the treated water increases initially and after
4-5 hrs, it starts to decrease. After $30 \mathrm{hrs,} \mathrm{the} \mathrm{fluoride} \mathrm{concentration}$ in the treated water reduces to $\sim 1.5 \mathrm{ppm}$, which is below the minimum concentration layer of fluoride in industrial wastewater. The maximum concentration of fluoride in the treated water is found after $\sim 3 \mathrm{hr}$ of operation, which reduces gradually with operation time. This indicates that the bacteria take some time to adjust in the continuous operation of the reactor. A similar observation has been reported recently during the fluoride removal in a bio-column reactor using SRB [17]. With the increase in flow rate value, the contact time of the water sample with the bio-layer increases. Due to this reason fluoride concentration in the treated water using a flow rate value of $18 \mathrm{hrs}$ is less than those obtained by flow rate values of $12 \mathrm{hrs}$ and $6 \mathrm{hrs}$. For lower flow rate values, the water sample gets lower contact time with adsorbent and at the initial stage of operation and it leaves the reactor before the bacteria of the bio-film cope up with the continuous operation. Hence, at the initial stage of operation the fluoride removal is less. With the increase in time, bacterial mass accommodates them in the continuous mode of operation, as a result of the observed effect of flow rate on the fluoride removal becomes negligible after $\sim 30 \mathrm{hrs}$. Hence, flow rate of $23 \mathrm{ml} /$ minutes is sufficient for the biotreatment process.

\section{Effect of bed height}

When we vary bed height keeping flow rate constant, we observe a change in contact time of the sample. Figs. 5-7 show the effect of changing bed height on the fluoride concentration in treated water at flow rate of 12,23 , and $40 \mathrm{ml} /$ minutes. Figures were in good agreement with the trend as mentioned in literature [16]. From Figs. 5-7, it is clear that

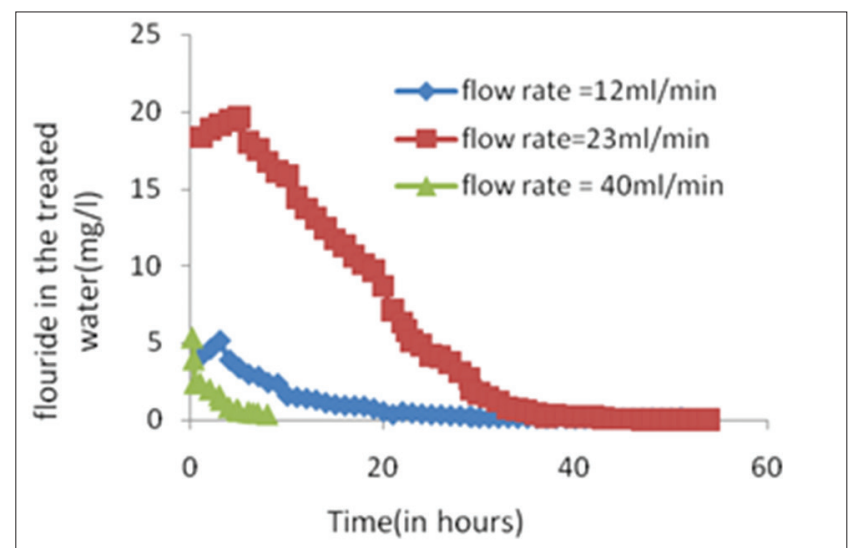

Fig. 4: Effect of flow rate on the fluoride removal in the biocolumn reactor (height $=100 \mathrm{~cm}$, initial fluoride concentration $=20 \mathrm{mg} / \mathrm{L}$ )

Table 4: Data of variable bed depth at a fixed flow rate in a fixed-bed biocolumn reactor for the removal of $20 \mathrm{mg} / \mathrm{l}$ of fluoride by java plum seeds (Bio adsorbent)

\begin{tabular}{|c|c|c|c|c|c|c|c|}
\hline$Q$ flow rate $\left(\mathrm{ml} /\right.$ minute $\left.\mathrm{cm}^{2}\right)$ & $\begin{array}{l}\text { Bed height } \\
(\mathrm{cm})\end{array}$ & $\begin{array}{l}\text { Bed volume } \\
\left(\mathrm{cm}^{3}\right)\end{array}$ & $\begin{array}{l}\text { Weight of } \\
\text { adsorbent } \mathrm{m}(\mathrm{g})\end{array}$ & EBRT (minute) & $V_{b}(L)$ & $\mathrm{T}_{\mathrm{b}}$ (hrs) & $\begin{array}{l}\text { Adsorbent exhaustion } \\
\text { rate }(\mathrm{g} / \mathrm{L})\end{array}$ \\
\hline $12 \mathrm{ml} /$ minutes & 20 & 1272.34 & 483.4 & 106.03 & 4.403 & 6 & 109.78878 \\
\hline & 60 & 3817.02 & 1451.9 & 318.0 & 12.104 & 17 & 119.952082 \\
\hline & 100 & 6361.7 & 2419.9 & 530.14 & 21.342 & 31 & 113.386749 \\
\hline $23 \mathrm{ml} /$ minute & 20 & 1272.34 & 483.4 & 55.319 & 22.783 & 18 & 21.2175745 \\
\hline \multicolumn{8}{|l|}{$0.3615\left(\mathrm{ml} /\right.$ minutes $\left.\mathrm{cm}^{2}\right)$} \\
\hline & 40 & 2544.68 & 969.1 & 110.639 & 43.472 & 31 & 22.2925101 \\
\hline & 60 & 3817.02 & 1451.9 & 165.957 & 63.696 & 45 & 22.79421 \\
\hline & 100 & 6361.7 & 2419.9 & 276.595 & 74.131 & 82 & 32.6435634 \\
\hline $40 \mathrm{ml} /$ minute & 20 & 1272.34 & 483.4 & 31.808 & 1.074 & 0.45 & 450.09311 \\
\hline \multicolumn{8}{|l|}{$0.6287\left(\mathrm{ml} /\right.$ minute $\left.\mathrm{cm}^{2}\right)$} \\
\hline & 40 & 2544.68 & 969.1 & 63.617 & 7.574 & 3 & 127.950885 \\
\hline & 60 & 3817.02 & 1451.9 & 152.68 & 12.084 & 3.16 & 120.150612 \\
\hline & 100 & 6361.7 & 2419.9 & 159.04 & 19.276 & 6 & 125.539531 \\
\hline
\end{tabular}

EBRT: Empty bed residence time 
fluoride concentration decreases to $1.5 \mathrm{ppm}$ which is MCP of fluoride in wastewater after 7, 12, 6 and $10 \mathrm{hrs}$ after starting reactor from point $\mathrm{P}_{1} \mathrm{P}_{2} \mathrm{P}_{3}$ and $\mathrm{P}_{5}$, respectively, when flow rate was $12 \mathrm{ml} /$ minutes. All of the data were recorded in Tables 4 and 5. Initially, bacteria took some time to settle them in the continuous flow of operation of the reactor From Figs. 4-6, we can observe that when we decreases bed height, decrease in contact time is noted which results into lower fluoride removal from waste water. After some time when bacteria are adjusted in the reactor, the effect of bed height tends to diminish.

\section{Effect of EBCT}

Fig. 8 shows the plot in which adsorption exhaustion rate is represented on Y-axis and X-axis is denoted by EBRT. This graph is plotted at various adsorbent bed heights $(20,40,60,100 \mathrm{~cm})$. From Figure, it can be clearly depicted that for flow rate $40 \mathrm{ml} /$ minutes the value of adsorbent exhaustion rate decrease gradually with increase in EBRT. In Table 4, we have recorded various data which validated that with an increase in bed depth we can observe an increase in $V_{b}, T_{b}$ and EBRT of the bio-column reactor. It is evident that with an increase in EBRT at a constant flow rate, we will get a higher value of bed volume, which gives access to treat more solution but results in lower adsorbent exhaust rate.

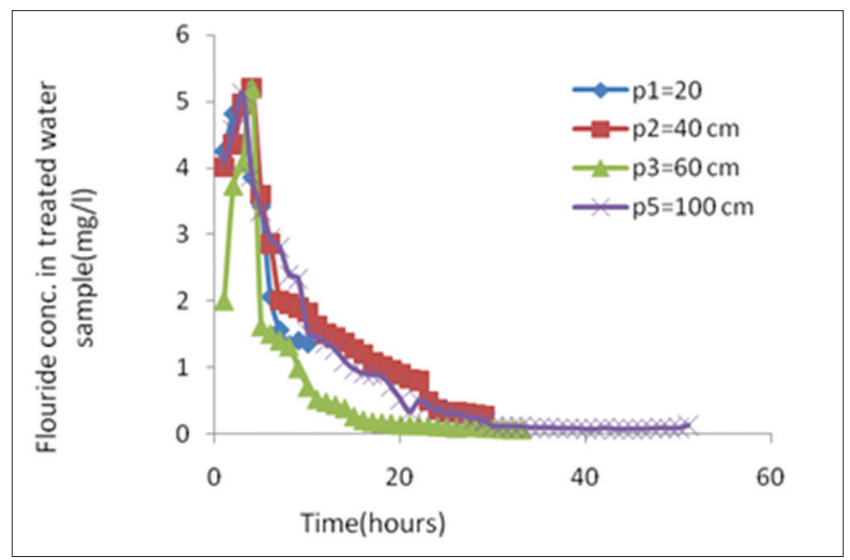

Fig. 5: Effect of bed height on fluoride removal in the biocolumn reactor (Flow rate: $12 \mathrm{ml} /$ minutes, initial fluoride concentration $=20 \mathrm{mg} / \mathrm{L}$ )

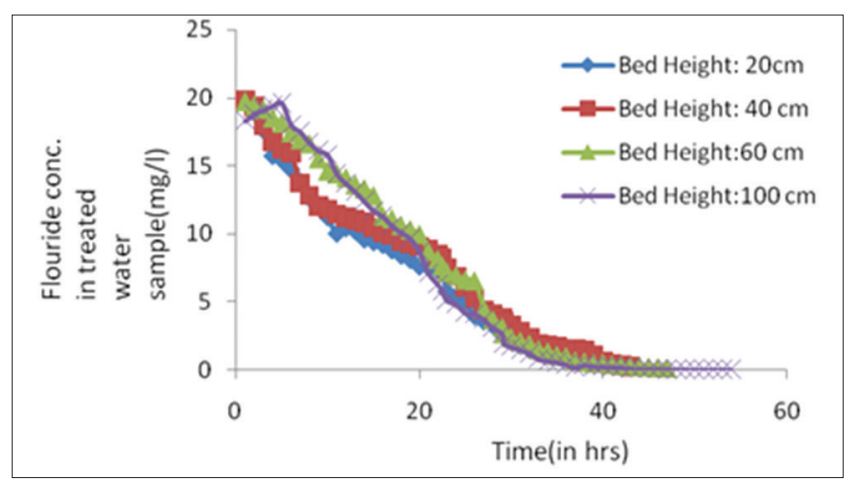

Fig. 6: Effect of bed height on fluoride removal in the biocolumn reactor (Flow rate: $23 \mathrm{ml} /$ minutes, initial fluoride concentration $=20 \mathrm{mg} / \mathrm{L}$ )
Variation of $\mathrm{pH}$ and dissolved oxygen (DO) of treated waste water with time

Another important point which is noted during the experiment is the slight change in the pH with the time as shown in Fig. 9 the graph plotted in Fig. 8 is for the waste water collected from top of bioreactor (height $=100 \mathrm{~cm}$ ) when flow rate of pollutant is $23 \mathrm{ml} /$ minutes. From Fig. 8, it is evident

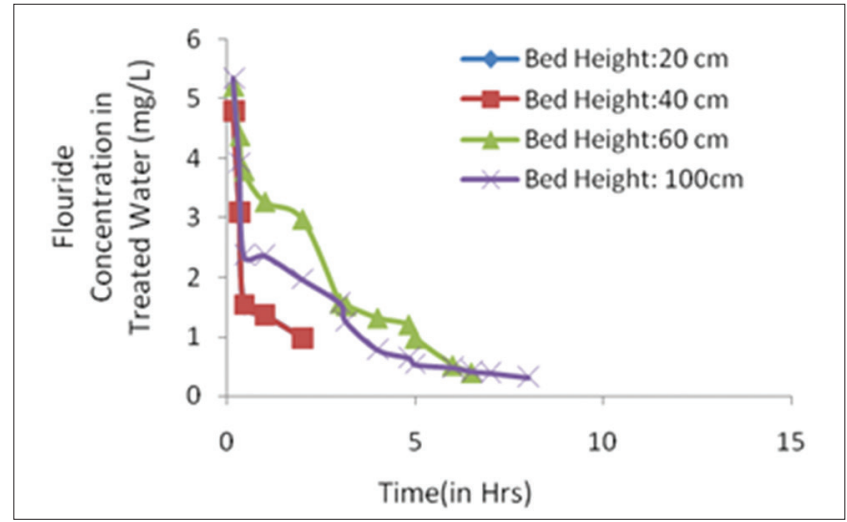

Fig. 7: Effect of bed height on fluoride removal in the biocolumn reactor (flow rate: $40 \mathrm{ml} / \mathrm{minute}$, initial fluoride concentration $=20 \mathrm{mg} / \mathrm{L}$ )

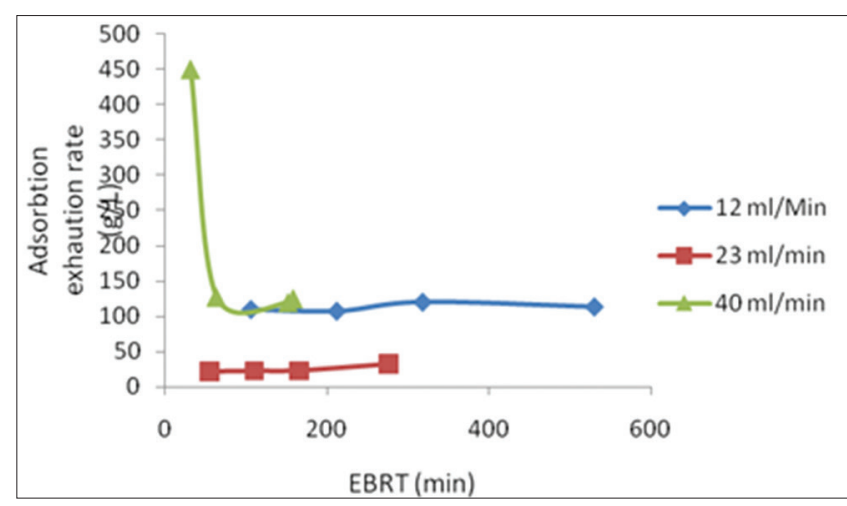

Fig. 8: Adsorbent exhaustion rate versus empty bed residence time model

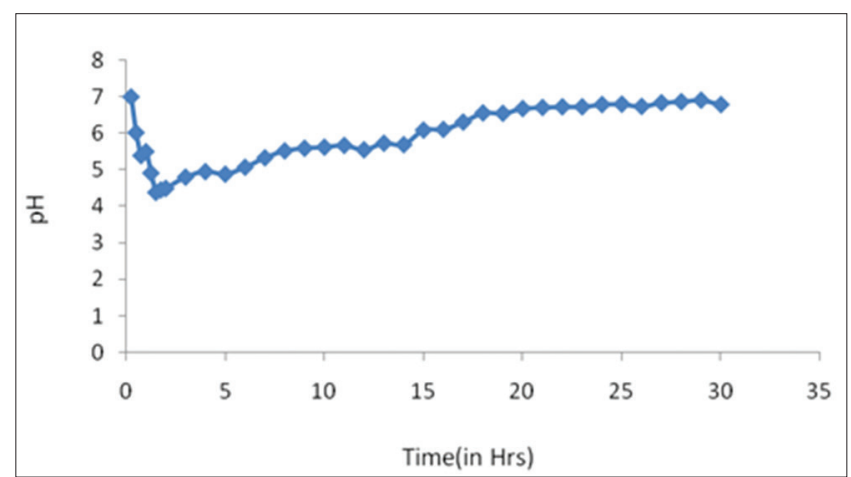

Fig. 9: Change of $\mathrm{pH}$ with time of operation in bio-column reactor

Table 5: Constant of BDST curve

\begin{tabular}{|c|c|c|c|c|c|c|c|c|}
\hline $\mathrm{Q}$ flow rate $\left(\mathrm{ml} /\right.$ minute $\left.\mathrm{cm}^{2}\right)$ & $\mathrm{V}(\mathrm{cm} / \mathrm{hr})$ & Slope $(\mathrm{hr} / \mathrm{cm})$ & Intercept (hr) & $\begin{array}{l}\text { Depth D } \\
\text { (cm) }\end{array}$ & $\mathrm{N}_{0}(\mathrm{mg} / \mathrm{L})$ & $\mathrm{K}\left(\mathrm{L} \mathrm{mg}^{-1} \mathrm{hr}^{-1}\right)$ & $X(\mathrm{mg} / \mathrm{g})$ & $\mathbf{R}^{2}$ \\
\hline 0.1886 & 11.316 & 0.311 & -0.628 & 2.011 & 70.66 & 0.2 & 0.170635 & 0.995 \\
\hline 0.3615 & 21.69 & 0.805 & -0.314 & 0.744 & 182.9 & 0.4 & 0.865102 & 0.992 \\
\hline 0.6287 & 37.722 & 0.064 & -0.384 & 166.52 & 1.74 & 0.327 & 0.110087 & 0.937 \\
\hline
\end{tabular}

BDST: Bed depth service time model 
that initially the $\mathrm{pH}$ decreases slightly and starts to increase after $2 \mathrm{hrs}$ of operation of the reactor, which signifies that the bacteria is adapted in the new environment. After around 25 hrs of operation, the $\mathrm{pH}$ reaches 7.5. A similar change in $\mathrm{pH}$ was reported recently on the arsenic removal using SRB in bio-column reactor $[16,17]$. The procedure and reason for such slight increase in $\mathrm{pH}$ is not well understood. However, some time back it has been reported that the reactions of molecular oxygen at the surface of the carbon results complex $\mathrm{C}_{\mathrm{x}} \mathrm{O}$ or $\mathrm{C}_{\mathrm{x}} \mathrm{O}_{2}$. This adsorbed oxygen complex, in neutral solution, is sufficiently active to cause an oxidation of water as per the following reaction $[18,19]$.

$\mathrm{C}_{\mathrm{x}} \mathrm{O}+\mathrm{H}_{2} \mathrm{O}=\mathrm{C}_{\mathrm{x}}+2 \mathrm{OH}^{-}$

The hydroxyl ion may combine with $\mathrm{H}_{2} \mathrm{O}$ resulting in a net increase in the $\mathrm{pH}$ of the solution [19].

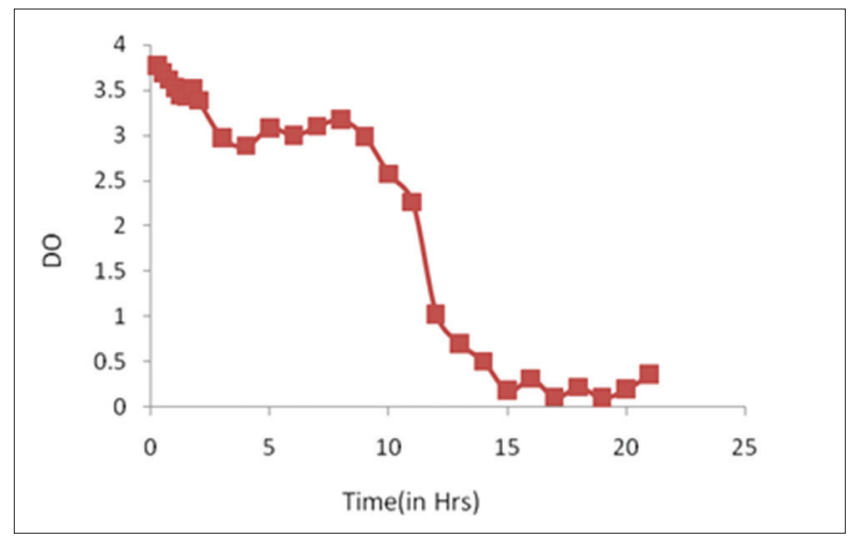

Fig. 10: Variation of dissolved oxygen with time
It is also observed that DO in treated wastewater is around $\sim 3.9 \mathrm{mg} / \mathrm{L}$ in starting but after $15-16 \mathrm{hrs}$ of operation it fell down to $0.19 \mathrm{mg} / \mathrm{L}$ as shown in Fig. 10. After that till the end of operation D0 remains more or less constant. The probable reason for sudden decrease in DO could be settlement of bacteria. Once the bacteria is settled DO also reaches a constant value.

\section{Characterization of java plum (bio-adsorbent)}

Scanning electron micrograph (SEM)

The surface morphology of the Java plum was examined by SEM. Figs. 11a and $b$ show the SEM of Java plum adsorbent used for adsorption studies. It was revealed from these figures that this adsorbent had irregular and porous surface. The difference in the adsorbent capacity of adsorbent was mainly due to difference in their surface porosity.

\section{Energy dispersive X-ray spectroscopy (EDAX)}

EDAX of Java plum before and after adsorption Fluoride ions are shown in Figs. 12 and 13 before and after adsorption of fluoride ions are shown

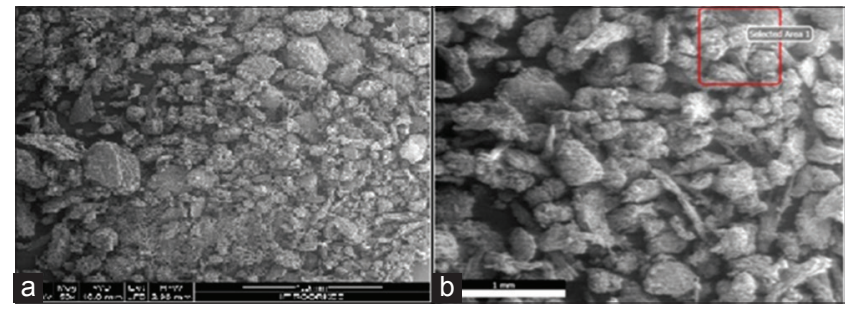

Fig. 11: Scanning electron micrograph micrograph of java plum seeds (a) before bio-adsorbtion/accumulation process (b) after bio-adsorption/accumulation process each shown at a magnification of $\times \mathbf{5 0}$

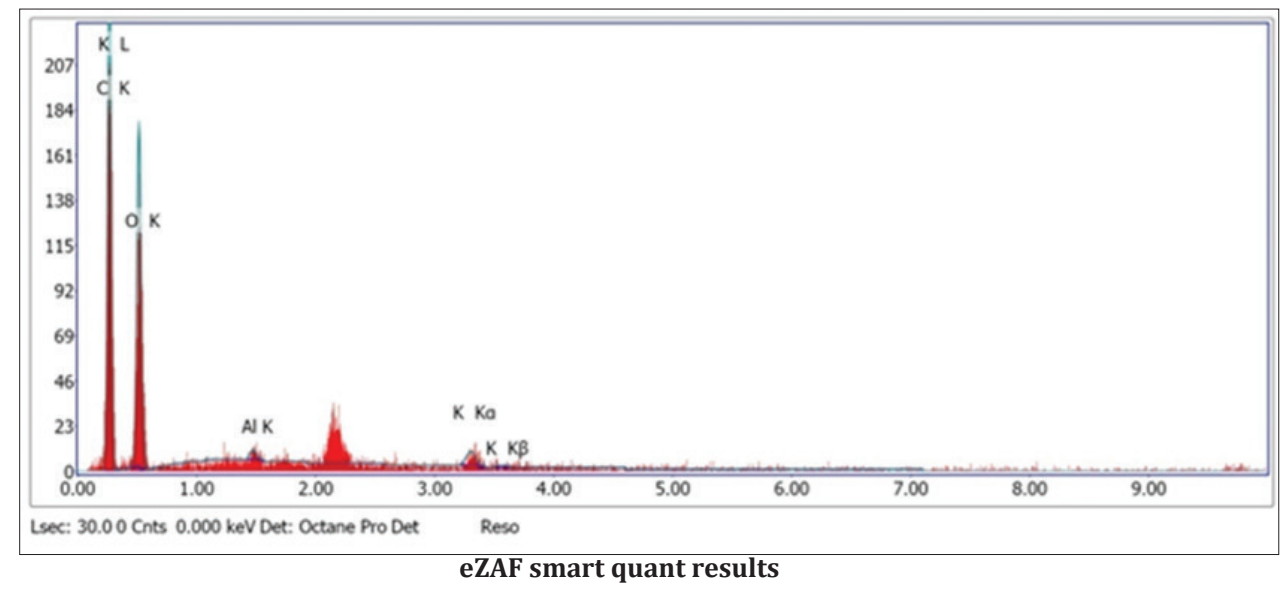

\begin{tabular}{llll}
\hline Element & Weight \% & Atomic \% & Error \% \\
\hline C K & 48.97 & 56.83 & 7.16 \\
O K & 48.33 & 42.11 & 51.9 \\
Al K & 0.61 & 0.31 & 51.49 \\
K K & 2.09 & 0.74 & 2.4 \\
\hline
\end{tabular}

Fig. 12: Energy dispersive X-ray spectroscopy image of java plum seeds before bio-adsorbtion/Accumulation process

Table 6: FTIR analysis for java plum adsorbent in tabular form

\begin{tabular}{|c|c|c|c|c|c|}
\hline $\begin{array}{l}\text { Wave number } \\
\left(\mathrm{cm}^{-1}\right)\end{array}$ & $3400-3500$ & $2500-3300$ & $1550-1650$ & $1370-1390$ & $970-1250$ \\
\hline compound & Amines & Carboxylic acids and derivatives & Amines & Alkanes & Alcohols and phenols \\
\hline Groups & $\begin{array}{l}\mathrm{N}-\mathrm{H}\left(1^{\circ} \text { amines }\right), \\
2 \text { bands }\end{array}$ & O-H (very broad) & $\begin{array}{l}\mathrm{NH}_{2} \text { Scissoring } \\
\left(1^{\circ} \text { amines }\right)\end{array}$ & $\mathrm{CH}_{2}$ and $\mathrm{CH}_{3}$ deformation & $\mathrm{C}-\mathrm{O}$ \\
\hline
\end{tabular}

FTIR: Fourier transform infrared 


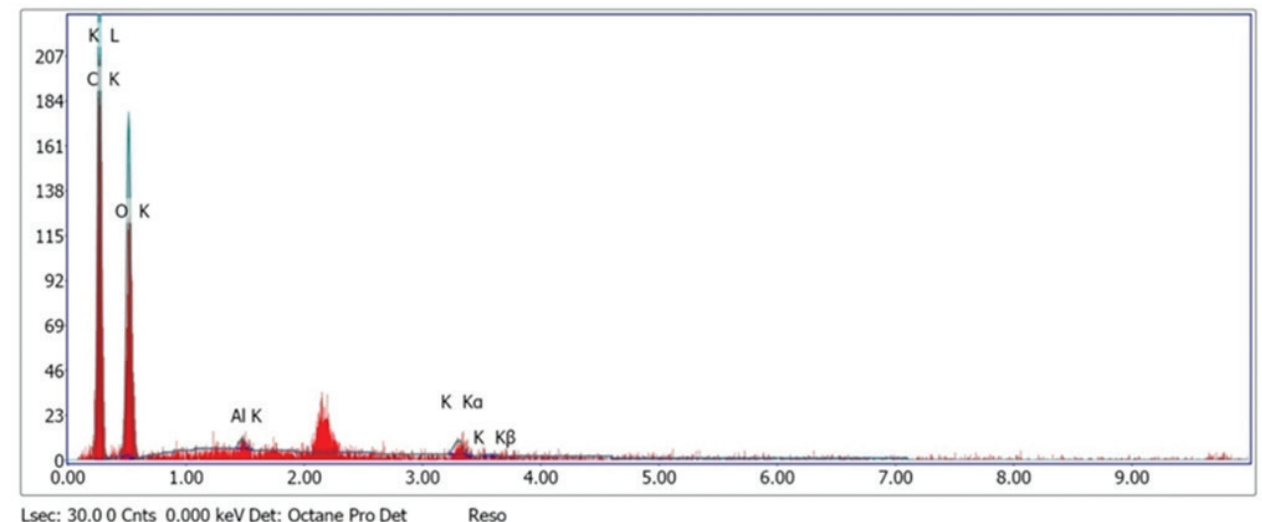

eZAF smart quant results

\begin{tabular}{llll}
\hline Element & Weight \% & Atomic \% & Error \% \\
\hline C K & 49.72 & 57.83 & 8.3 \\
O K & 45.64 & 39.85 & 52.39 \\
F K & 0.37 & 0.27 & 0.37 \\
Na K & 1.53 & 0.93 & 3.62 \\
Al K & 0.55 & 0.29 & 2.36 \\
Cl K & 1.5 & 0.59 & 4.98 \\
Ca K & 0.68 & 0.24 & 65.93 \\
\hline
\end{tabular}

Fig. 13: Energy dispersive X-ray spectroscopy image of java plum seeds after bio-adsorbtion/accumulation process

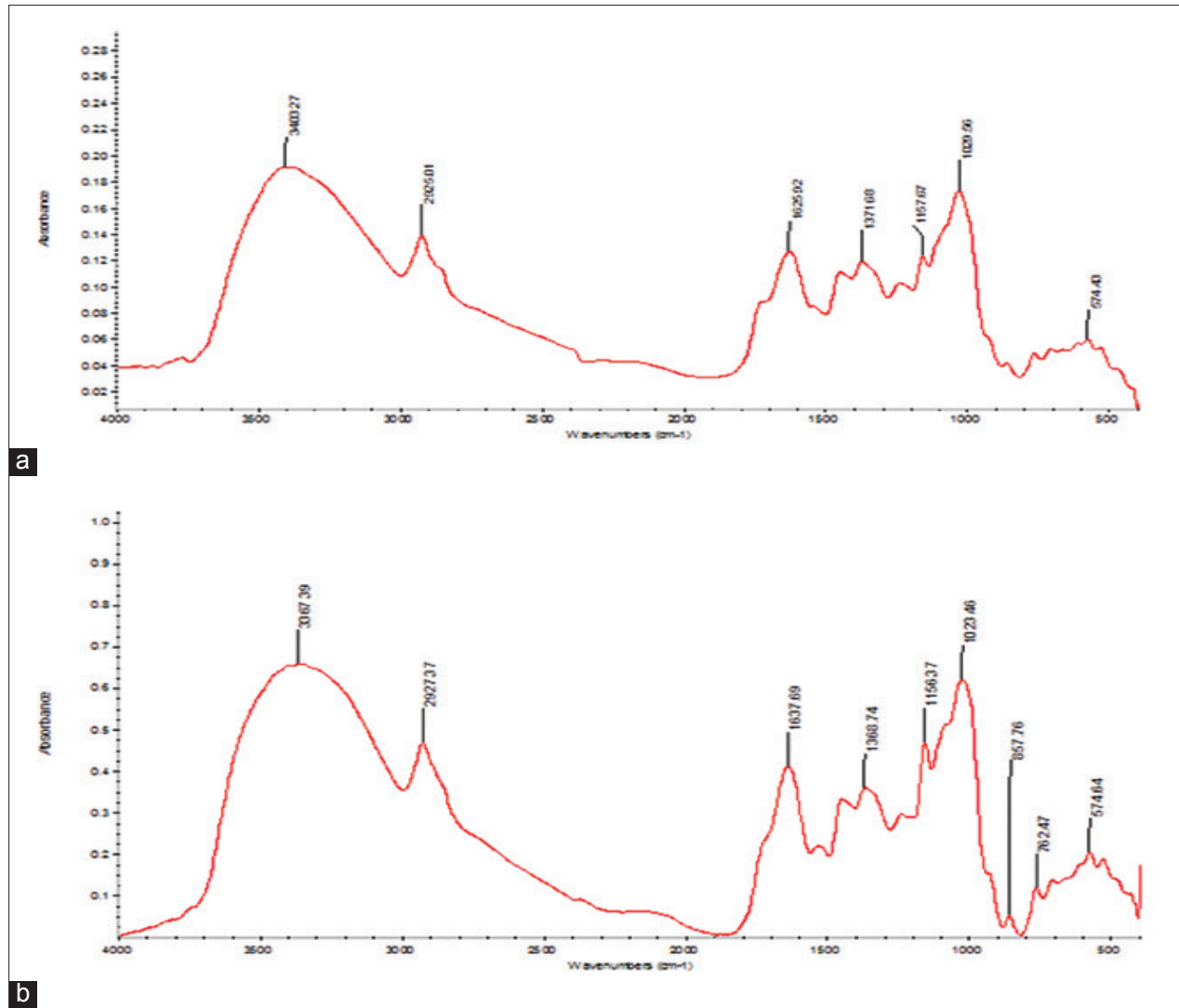

Fig. 14: (a) Fourier transform infrared analysis of java plum before adsorption of fluoride. (b)Fourier transform infrared analysis of java plum after adsorption of fluoride

Fig. 18a it is clear that various element such as carbon, oxygen and very small amount of calcium were present in virgin adsorbent but fluoride was not present there. When the EDAX of the adsorbent was carried out after the adsorption of fluorides ion, fluoride was present on the surface of adsorbent about $0.59 \mathrm{wt} \%$ which confirmed the adsorption of fluoride by this adsorbent.

\section{Fourier transform infrared (FTIR)}

Functional groups present in bio-adsorbents before and after adsorption of bio-adsorbents were determined using Fourier transform infrared spectroscopy (Thermo Nicolet, Magna 7600). The samples were prepared by pellet (pressed disk) method by mixing the same amount of $\mathrm{KBr}$ in each sample. The selected spectral range was from 
4000 to $400 \mathrm{~cm}^{-1}$ Functional groups present on the surface of the peels are determined by the FTIR spectroscopy method. Figure shows FTIR spectra on various adsorbents, on the surface of adsorbent many functional groups are present.

The range of different wave number assign the functional groups present in the adsorbent. The amine bond stretching lie in the wave range of $3400-3500 \mathrm{~cm}^{-1}$, similarly for the very broad $\mathrm{O}-\mathrm{H}$ (2500-3300 $\left.\mathrm{cm}^{-1}\right), \mathrm{NH}_{2}$ Scissoring stretching (1550-1650 $\mathrm{cm}^{-1}$ ), alkanes (1370-1390 $\mathrm{cm}^{-1}$ ), alcohols and phenols ion stretching $\left(970-1250 \mathrm{~cm}^{-1}\right)$.

\section{CONCLUSION}

From the above discussions the following conclusions are drawn:

- The bio-column reactor is capable to reduce the concentration of the pollutants in the effluent water below their permissible limit.

- Bio-column reactor must be backwashed for effective continuous operation.

- At the initial stage, the flow rate and bed height have a significant influence on the removal of fluoride from the contaminated water. However, after some time of operation (approximately 24-25 hrs) such influence is negligible under the experimental conditions.

- Fluoride is removed after $\sim 24$ hrs of operation.

- DO reduce along the bed height of the reactor, which supports the aerobic nature of the bacteria.

- $\quad \mathrm{pH}$ of the solution slightly decreases initially for the $1^{\text {st }} \mathrm{hs}$ and increases within small range (6.5-7.5).

- The BDST model was successfully applied to analyze the column performance and to evaluate the model parameter. The BDST equations of linear relationship between the bed depth and the service time were obtained with $\mathrm{R}^{2}=0.995,0.992$ and 0.937 for 12 , 23 and $40 \mathrm{ml} /$ minutes flow rate, respectively.

- The EBRT model which optimizes the EBRT and the sorbent utilization rate was successfully applied with optimum contact time greater than about $159.04,276.59$ and 530.14 minutes for 40,23 and $12 \mathrm{ml} /$ minutes flow rates, respectively, with the corresponding usage rate of $125.54,32.64$ and $113.39 \mathrm{~g} / \mathrm{L}$. The optimum dose for batch system was $3 \mathrm{~g} / 100 \mathrm{~mL}$

\section{REFERENCES}

1. Manahan, SE. Environmental Chemistry. $6^{\text {th }}$ ed. Chelsea (USA): Lewis Publishers, Fluoride; 1994.
2. Iindian Standard. Drinking Water-Specification. $2^{\text {nd }}$ Revision. New Delhi: IS, 10500; 2005.

3. Amor Z, Malki S, Taky M, Bariou B, Mameri N, Elmidaouri A. Optimization of fluoride removal from brackish water by electrodialysis. Desalination 1998;120:236-71.

4. Hasany SM, Chuudhary, MH. Sorption potential of Haro River quartz for the removal of antimony from acidic aqueous solution. Appl Radioactiv Isot 1996;47(4):467-71.

5. Cohen D, Conrad HM. Fluoride removal membrane system in Lakeland California USA. Desalination 1998;117(1):19-35.

6. Wang Y, Reardon EJ. Activation and regeneration of a soil sorbent for de-fluoridation of drinking water. Appl Geochem 2001;16(5):531-9.

7. Lounici, H. Study of a new technique for fluoride removal from water. Desalination 1997;114:241-51.

8. Srimurali M, Pragathi A, Karthikeyan J. A study on removal of fluorides from drinking water by adsorption onto low-cost materials. Environ Pollut 1998;99(2):285-9.

9. Afzal M, Iqbal S, Rauf S, Zafar MK. Characteristics of pheno biodegradation in saline solutions by monocultures of Pseudomonas aeruginosa and Pseudomonas pseudomallei. J Hazard Mater 2007;140:60-6.

10. Perrich JR. Activated Carbon Adsorption for Wastewater Treatment. Boca Raton: CRC Press; 1981.

11. McKay G, Bino MJ. Simplified optimization procedure for fixed bed adsorption systems. Water Air Soil Pollut 1990;51:33-41.

12. Negrea L, Lupa M, Negrea, P. Experimental and modelling studies on as (III) removal from aqueous medium on fixed bed column. Chem Bull Politehnica Univ Timisoara Romania Ser Chem Enviro Eng 2011;56(70):2.

13. Guo H, Stuben D, Berner ZA, Kramar U. Adsorption of arsenic species from water using activated siderite-hematite column filters. J Hazard Mater 2007;151:628-35.

14. Hutchins RA. New methods simplify design of activated carbon system Am J Chem Eng 1973;80:133-8.

15. Mekay G, Blair HS, Gardner JR. The adsorption of dyes on to chitin in fixed- bed columns and batch adsorbers. J Appl Polym Sci 1984;29:1400-9.

16. Mondal P, Majumder CB, Mohanty B. Treatment of arsenic contaminated water in a laboratory scale up-flow bio-column reactor. J Hazard Mater 2005;B153:136-45.

17. Jong T, Parry DL. Removal of sulfate and heavy metals by sulfate reducing bacteria in short-term bench scale upflow anaerobic packed bed reactor runs. Water Res 2003;37(14):3379-89.

18. Mondal P, Majumder CB. Treatment of resorcinol and phenol bearing wastewater by simultaneous adsorption biodegradation (SAB): Optimization of process parameters. Int J Chem React Eng 2007;5:S11-5

19. Bhatt DJ, Bhargava DS, Panesar PS. Effect of $\mathrm{pH}$ on phenol removal in moving media reactors. Indian J Enviro Health 1983;25:261-7. 